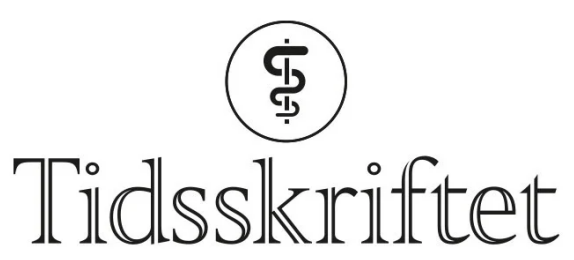

DEN NORSKE LEGEFORENING

\title{
Surnadal legesenter
}

\section{LEGELIVET}

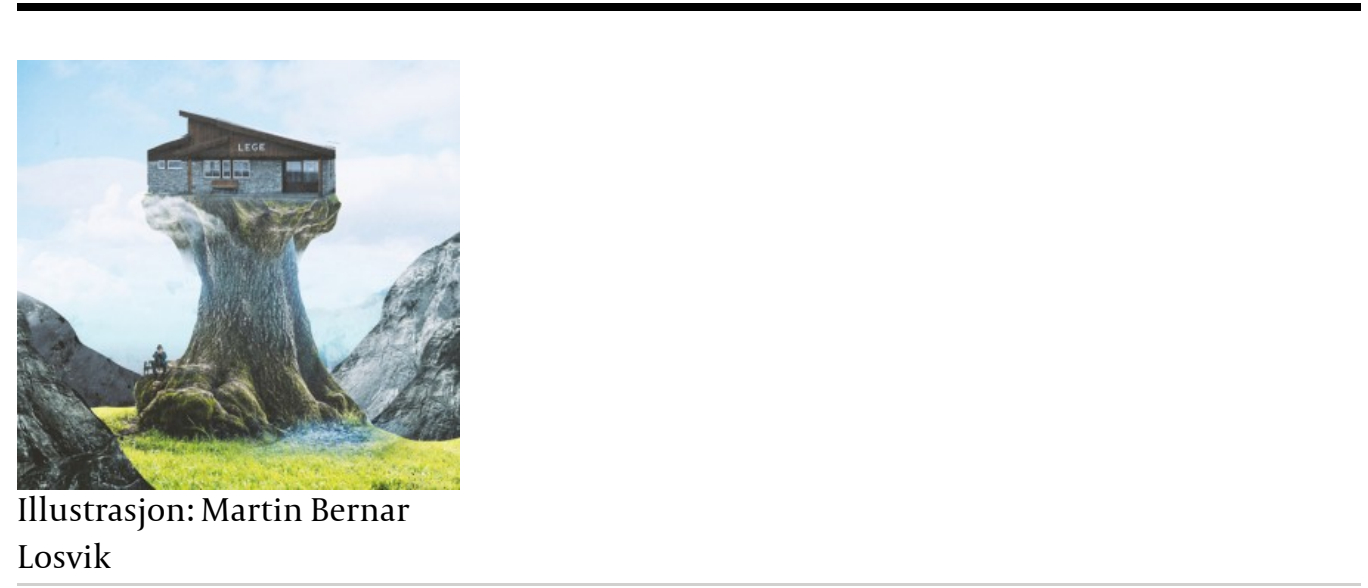

\section{Tabell}

Surnadal er en kommune på Nordmøre med ca. 6000 innbyggere. Kommunen består av flere daler og mange fjorder og ligger ved foten av vakre Trollheimen. Surnadal

/sites/tidsskriftet.no/files/2014-Legelivet-Intro-1.svg legesenter ligger på Skei, som er administrasjonssenteret i kommunen. Her jobber seks leger inkludert turnuslege. Nærmeste sykehus er Orkdal sjukehus i Sør-Trøndelag, 80 kilometer unna.

Publisert: 16. september 2014. Tidsskr Nor Legeforen. DOI: 10.4045/tidsskr.14.1083

(C) Tidsskrift for Den norske legeforening 2023. Lastet ned fra tidsskriftet.no 26. april 2023. 